\title{
Correction to: Cross-country abortion travel to England and Wales: results from a cross-sectional survey exploring people's experiences crossing borders to obtain care
}

\author{
Camille Garnsey ${ }^{1}$, Giulia Zanini ${ }^{2}$, Silvia De Zordo ${ }^{2}$, Joanna Mishtal ${ }^{3}$, Alexandra Wollum ${ }^{1}$ and Caitlin Gerdts ${ }^{{ }^{*}}$ (i)
}

\section{Correction to: Reprod Health (2021) 18:103} https://doi.org/10.1186/s12978-021-01158-z

After publication of this article [1], the authors reported three adjustments:

- In Table 1, second column, the percentage of travelers from the Republic of Ireland should be "90\%" instead of "98\%". The $\mathrm{n}(65)$ is correct.

- In Table 3, fourth column, the first "Prefer not to answer/no response" row should reflect the sum of the second and third columns, and needs to be "5(5\%)" instead of "1(1\%)".

- In Table 4, second column, there was an extraneous " 0 " in the "Cost of abortion procedure"-part after "I did not have to pay for my abortion". This " 0 " should be removed.

The original article [1] has been updated.

\begin{abstract}
Author details
${ }^{1}$ Ibis Reproductive Health, 1736 Franklin St, Suite 600, Oakland, CA 94612, USA. ${ }^{2}$ Department of Anthropology, University of Barcelona, Montalegre, 6-8, 08001 Barcelona, Spain. ${ }^{3}$ Department of Anthropology, University of Central Florida, 4297 Andromeda Loop, Orlando, FL 32816, USA.
\end{abstract}

Published online: 15 November 2021

\section{Reference}

1. Garnsey C, Zanini G, De Zordo S, Mishtal J, Wollum A, Gerdts C. Cross-country abortion travel to England and Wales: results from a cross-sectional survey exploring people's experiences crossing borders to obtain care. Reprod Health. 2021;18:103. https://doi.org/10.1186/ s12978-021-01158-Z.

\section{Publisher's Note}

Springer Nature remains neutral with regard to jurisdictional claims in published maps and institutional affiliations. to the material. If material is not included in the article's Creative Commons licence and your intended use is not permitted by statutory regulation or exceeds the permitted use, you will need to obtain permission directly from the copyright holder. To view a copy of this licence, visit http://creativecommons.org/licenses/by/4.0/. The Creative Commons Public Domain Dedication waiver (http://creativecommons.org/publicdomain/zero/1.0/) applies to the data made available in this article, unless otherwise stated in a credit line to the data. 